Modern Asian Studies 54, 5 (2020) pp. I446-I482. (C) The Author(s) 2020. This is an Open Access article, distributed under the terms of the Creative Commons Attribution licence (http://creativecommons.org/licenses/by/4.o/), which permits unrestricted re-use, distribution, and reproduction in any medium, provided the original work is properly cited.

doi:Io.IoI7/Soo26749XIgooo404 First published online 3 January 2020

\title{
Foreign Correspondents in the East Asian Cold War: The Sino-fapanese journalist exchange of 1964 *
}

\author{
CASPER WITS \\ Faculty of Humanities, Leiden University \\ Email: c.wits@hum.leidenuniv.nl
}

\begin{abstract}
This article examines the importance of the exchange of foreign correspondents between Japan and China from 1964, during a period of the Cold War when the two countries did not have official ties. Favourable political circumstances in the first half of the ig6os led to a brief window of opportunity for an improved relationship between China and Japan, during which this unique exchange took place. The article attempts to shed light on the significance of the exchange within the broader context of Chinese foreign policy and Sino-Japanese relations during the Cold War. Thereby it will clarify the importance of the 1960-1964 period for the longer rapprochement process that would come to fruition in 1972 with the establishment of diplomatic relations. The exchanges of 1964 were seen by participants as an important first step on the way towards official ties. For the Chinese the importance of a relationship with Japan in this period, and, by extension, the importance of the journalist exchange, is shown by the involvement of an unusually high number of journalists from both countries. This article argues that the Chinese leadership's desire for the journalist exchange was rooted in a craving for accurate knowledge about Japan, especially concerning specific political trends and economic developments. This enthusiasm was matched by pro-China politicians in Japan, who also felt that the journalists' presence would enable the Chinese to base their Japan policy on a broader variety of sources, extending beyond information merely gathered through contacts in the Japanese left.
\end{abstract}

* I want to thank Kato Chihiro, former Beijing correspondent of Asahi Shimbun, for introducing me to the journalists I interviewed for this article. I also want to express my gratitude to Barak Kushner for reading and commenting on a draft version of this article, and to the editor and anonymous reviewers for their helpful comments and suggestions. 


\section{Introduction}

After the founding of the People's Republic of China (PRC) in I949, only a limited number of non-communist countries recognized the new government, whereas the United States and Japan officially recognized Chiang Kai-shek's Republic of China (ROG) regime in Taiwan. This situation lasted until I972, by which time the PRC had achieved diplomatic normalization with Japan as well as with Western European countries. Despite the fact that the United States lagged behind its allies and did not establish official relations with the PRC until 1979, China's opening to the West in the I970s has been studied from a predominantly American perspective. However, recent scholarship has brought to the fore the rich interactions between China and several countries from the capitalist bloc in the decades prior to i972. ${ }^{1}$ Though constricted because of Cold War realities, these interactions laid the groundwork for the rapid improvement in China's international standing in the I970s and, as Romano and Zanier have argued, this means that we must understand the rapprochement processes as beginning in the I950s. $^{2}$ While these recent studies have drawn attention to China's efforts to engage with the capitalist world by focusing mostly on Beijing's cultivation of ties with influential political and business figures, this article seeks to build on these studies by drawing attention to the part played by journalists in these efforts, looking specifically at their role in Sino-Japanese relations during the first half of the ig6os. ${ }^{3}$ A closer look at this moment can shed light on

\footnotetext{
${ }^{1}$ For Western Europe, see for example: Martin Albers, Britain, France, West Germany and the People's Republic of China, I969-1982: The European Dimension of China's Great Transition (London: Palgrave Macmillan, 2016); Angela Romano and Valeria Zanier (eds), Modern Asian Studies 5I.I (2017), Special issue: Circumventing the Cold War: The parallel diplomacy of economic and cultural exchanges between Western Europe and Socialist China in the I950s and I96os. For Japan, see: Amy King, China-fapan Relations after World War Two: Empire, Industry and War, I949-197I (Cambridge: Cambridge University Press, 2016); Yoshihide Soeya, Japan's Economic Diplomacy with China, 1945-1978 (Oxford: Clarendon Press, 1998).

${ }^{2}$ Angela Romano and Valeria Zanier, 'Circumventing the Cold War: The parallel diplomacy of economic and cultural exchanges between Western Europe and Socialist China in the I950s and ig6os: An introduction'. Modern Asian Studies 5I.r (2017), p. 9.

${ }^{3}$ This article also adds to a new and growing body of research on foreign correspondents during the Cold War. While this is not a widely studied subject, important recent scholarship on the Soviet-American case, especially by Dina Fainberg, has begun to remedy this. See: D. Fainberg, 'Notes from the Rotten West, Reports
} 
the broader rapprochement process that would eventually lead to diplomatic normalization in 1972.

Due to the absence of official relations, the PRC faced a particular set of challenges in its early decades with regard to its interactions with foreigners from capitalist countries. As Anne-Marie Brady has shown in her detailed study on the subject of China's waishi (waijiao shiwu; literally 'diplomatic matters') with Western countries in this period, a priority was to cultivate ties with numerous 'foreign friends' outside of the immediate government sphere and thereby 'subvert and bypass the policies of unfavourable governments'. Ideally, these potential allies would be influential people in their own countries and would therefore be able to mobilize domestic support for the Chinese government. ${ }^{5}$ This made the invitation to and interaction with foreigners a vital and integrated part of Chinese foreign policy, which led to the streamlining of a unique set of 'techniques of hospitality'. ${ }^{6}$ These contacts were orchestrated by carefully trained cadres and were fine-tuned to align with Beijing's goals with regard to each country. In addition to the long-term goal of achieving diplomatic recognition of the PRC, some important goals of this 'people's diplomacy' or 'people-to-people diplomacy' were to influence public opinion abroad and to split blocs of power in countries opposed to the PRG. ${ }^{7}$ This article attempts to shed light on how the Chinese integrated journalism with waishi and people's diplomacy towards Japan, both in the case of the work of Chinese journalists reporting on Japan and the interaction with Japanese journalists.

from the Backward East: Soviet and American Foreign Correspondents in the Cold War, I945-I985', PhD thesis, Rutgers University, 2012; D. Fainberg, 'Unmasking the Wolf in Sheep's Clothing: Soviet and American campaigns against the enemy's journalists, I946-I953'. Cold War History I5.2 (2015), pp. 155-178. See also: Rósa Magnúsdóttir, 'Cold War Correspondents and the Possibilities of Convergence: American journalists in the Soviet Union, I968-i979'. The Soviet and Post-Soviet Review 41.I (2014), pp. 33-56. For an interesting overview of the lives of Western journalists in China during this period, see: Beverly Hooper, Foreigners under Mao: Western Lives in China, 1949-1976 (Hong Kong: Hong Kong University Press, 2016), pp. I25-I59.

${ }^{4}$ Anne-Marie Brady, Making the Foreign Serve China: Managing Foreigners in the People's Republic (Lanham, MA: Rowman and Littlefield, 2003), p. 23.

${ }^{5}$ Ibid., p. 9o.

${ }^{6}$ Julia Lovell, 'The Uses of Foreigners in Mao-era China: "Techniques of hospitality" and international image-building in the People's Republic, 1949-1976'. Transactions of the Royal Historical Society 25 (2015), p. I35.

\footnotetext{
${ }^{7}$ Brady, Making the Foreign Serve China, p. 23.
} 
Regarding the latter aspect, Brady has shown that in 1954, Premier Zhou Enlai, who was also the foreign minister, established five principles for dealing with foreign journalists. ${ }^{8}$ Cadres were urged to 'selectively and deliberately make friends' with journalists, who could serve to get the Chinese Communist Party's (CCP) message out to the world. ${ }^{9}$ While, unsurprisingly, many of these journalists were progressives naturally sympathetic to the Chinese communists, ${ }^{10}$ we will see that by the ig6os the PRC leadership was keen to move beyond those who were already supportive of Beijing in their approach to journalism and foreign correspondence.

In the first half of the ig6os, the economic devastation of the Great Leap Forward famine and the loss of Soviet economic support (in the wake of the Sino-Soviet split) had made the further cultivation of foreign trade links an urgent necessity for the PRC. The I960-I964 period would see a series of breakthroughs in China's relations with Western Europe and Japan. Amy King has shown that in the early ig6os Zhou Enlai and those around him looked to Japan as an East Asian model of how to use technology to modernize the economy and thereby 'catch up' with the West. ${ }^{11}$ Throughout the I950s, China had already begun to cultivate limited trade ties with Japan, leading to the signing of several 'nongovernmental' trade agreements. The early ig6os saw successful efforts to drastically expand trade links, focusing on major Japanese firms and culminating in the establishment of so-called 'LT (Liao-Takasaki) Trade' in ig62. An important breakthrough came on i9 April I964 with the agreement to establish trade liaison offices in Beijing and Tokyo, which reflected the rapidly growing trade between

\footnotetext{
${ }^{8}$ The five principles were: ' $\mathrm{I}$. Do not reject those who come, but be discriminating in how you treat them. 2. Be prudent, but not overcautious; maintain secrecy but do not be mysterious; take the initiative but do not act rashly. 3. Reply to reporters' questions; do not overuse 'No comment.' 4. As for provocations, rebut them in a principled manner, but do not get aggressive. 5. Hospitality towards foreign reporters should include questions and answers, it should lead us to a greater awareness of the situation, and [through it] we should selectively and deliberately make friends.' See: Brady, Making the Foreign Serve China, p. 98.

${ }^{9}$ Ibid., pp. 51, 52, $9^{8}$.

${ }^{10}$ The most famous of the leftist journalists cultivated by the CCP leadership was American journalist Edgar Snow, who in the I93os and later in the early I96os wrote influential books eulogizing the CGP and the PRC leadership. See: E. Snow, Red Star over China (London: Victor Gollancz, I937); E. Snow, Red China Today: The Other Side of the River (London: Victor Gollancz, 1963).

${ }^{11}$ King, China-Fapan Relations after World War Two, pp. 165-205.
} 
the two countries that would result in Japan becoming China's largest trade partner in I965. While the expansion of trade and the establishment of trade offices were the most important developments in Sino-Japanese relations at this time and have therefore received most scholarly attention, ${ }^{12}$ less well-known is that on the same day the Sino-Japanese Journalist Exchange Agreement was signed, which resulted in the permanent exchange of news correspondents. Through an analysis of this often-overlooked journalist exchange between Beijing and Tokyo we can take a further step towards completing our understanding of the history of Sino-Japanese relations in the Cold War.

This article will argue that in the context of rapidly improving economic and political ties, the importance of the Sino-Japanese journalist exchange for the Chinese leadership lay in a craving for accurate knowledge about Japan. It thereby serves as an example of Zhou's desire to use interactions with journalists to inform themselves of the outside world, 'leading to greater awareness'. A central concern shared by both sides in the exchange was that the permanent presence of journalists would enable the Chinese leadership to engage with, and formulate policy on, Japan based on information that would not just come from the Japanese left. Beijing's reliance on limited and biased sources was considered a problem by both the Chinese leadership and Japanese politicians and was seen as an obstacle to the goal of placing relations on a more solid footing. In the mid-rg6os, when the presence of Chinese citizens in Japan and vice versa was still limited, the journalists were to become a rare conduit for information and would serve Beijing as sources upon which policy could be based. An example of this was the use of both the Chinese and Japanese journalists to gain up-to-date information during the Japanese prime ministerial succession in November I964. It was feared an anti-China politician could derail much of the progress made on trade and other issues, as had happened during the tenure of Kishi Nobusuke (1957-1960). For the Chinese, the fact that there was a permanent presence of trade liaison officers and journalists in Japan and vice versa from 1964 was seen as an important step on the way to diplomatic normalization. That the exchange was indeed part of a new era in Sino-Japanese relations is shown by the fact that although a deterioration in relations had led to a complete breakdown of trade ties

\footnotetext{
${ }^{12}$ See, for example: Soeya, Japan's Economic Diplomacy with China; King, China-fapan Relations after World War Two; Mayumi Itoh, Pioneers of Sino-Japanese Relations: Liao and Takasaki (New York: Palgrave Macmillan, 2012).
} 
in the 1950s, when relations deteriorated again in the second half of the I96os, a lot of the gains made in the I96o-Ig64 period would not be reversed.

This article will examine the road that led towards achieving the journalist exchange, as well as the experiences of the journalists who were part of the exchange between Beijing and Tokyo from September i964. Looking initially at the first generation of Chinese correspondents in Tokyo, we will examine the extent to which they were encouraged to cultivate relations with those in Japan not already sympathetic to Beijing, something considered crucial for gaining an accurate understanding of the country. As for the Japanese journalists in China, their case was striking not only because there were far more of them than of journalists from other (even socialist) countries, but also because they were given greater access to the leadership in the person of Liao Chengzhi. A close confidant of Zhou Enlai who had grown up in Tokyo and was fluent in Japanese, Liao was the country's foremost expert on Japan and responsible for the management of China's Japan policy. A Central Committee member and director of the Overseas Chinese Affairs Office, he had been briefly head of the Xinhua News Agency prior to I949 and would become a pivotal figure in bringing about and managing the journalist exchange. ${ }^{13}$ Access for the Japanese correspondents was achieved by creating a unique space for the exchange of ideas and information between the Japanese and Liao: a monthly 'breakfast meeting', held at Hefeng, the sole Japanese restaurant in Beijing at the time, was established especially to facilitate Sino-Japanese exchanges. This stands in marked contrast to the rather limited role of Western journalists in China in the I96os, whose presence, according to Beverly Hooper in her chapter on the subject, was regarded by Beijing as merely a 'necessary evil to allow China to send a few of its own media representatives abroad'. ${ }^{14}$

Based on first-hand accounts from journalists' memoirs and diaries, as well as interviews with three of the last surviving participants in the journalist exchange of 1964 , as well as with the manager of Hefeng, this article will explore the content and political significance of the exchange.

${ }^{13}$ For an overview of the life and work of Liao Chengzhi, see: Kurt Werner Radtke, China's Relations with Japan, 1945-1983: The Role of Liao Chengzhi (Manchester: Manchester University Press, I990); and Itoh, Pioneers of Sino-fapanese Relations.

${ }^{14}$ Hooper, Foreigners under Mao, p. I25. 


\section{Sino-Japanese journalist interaction in the r950s}

In the early I950s the newly founded PRC faced relative international isolation, with many countries outside of the Soviet bloc not recognizing the new government, a situation that was exacerbated by the Korean War. Nonetheless, the Chinese leadership pursued trade ties with countries it did not have official relations with, promoting nongovernmental trade links as part of its so-called people's diplomacy. While trade with capitalist nations would become of vital importance after the Sino-Soviet split in the early I960s, several scholars have shown that Beijing was already proactively considering alternative markets to the USSR in the I950s, efforts that were seen by many involved as steps towards official recognition of the PRC. ${ }^{15}$ The official position of the Chinese government was to make a clear distinction between hostile governments and their people, with Beijing always opposed only to the former, but willing to engage and trade with the latter. ${ }^{16}$ This served to educate the Chinese people about why trade was conducted with supposedly hostile nations and also contributed to making 'foreign friends', who might not share the views of their governments, in the countries in question. The limited opportunities for interaction between China and Japan were usually related to this promotion of trade, and trade negotiations led to the signing of several nongovernmental trade agreements throughout the I950s. These negotiations took place between Chinese government representatives and progressive Japanese business organizations representing mostly small and medium sized enterprises (SMEs) that were pro-China. ${ }^{17}$ The progress made on trade in the I950s was highly prone to setbacks due to rapid changes in the political sphere, especially when the

${ }^{15}$ Angela Romano, 'Waiting for de Gaulle: France's ten-year warm-up to recognizing the People's Republic of China'. Modern Asian Studies 51.I (2017), pp. 44-77; Giovanni Bernardini, 'Principled Pragmatism: The Eastern Committee of German Economy and West German-Chinese relations during the early Cold War, I949-1958'. Modern Asian Studies 5I.I (2017), pp. 78-106; Valeria Zanier, “Energizing” Relations: Western European industrialists and China's dream of self-reliance. The case of Ente Nazionale Idrocarburi (1956-1965)'. Modern Asian Studies 51.I (2017), pp. 133-169; Albers, Britain, France, West Germany and the People's Republic of China, pp. I3-34; King, China-Japan Relations after World War Two, pp. 50-126.

${ }^{16}$ Brady, Making the Foreign Serve China, p. 23.

${ }^{17}$ For an overview of Sino-Japanese trade in the I950s, see: Soeya, Japan's Economic Diplomacy with China, pp. 20-44; King, China-Japan Relations after World War Two, pp. 90-I64. 
conservative right-winger Kishi Nobusuke became Japanese prime minister in 1957 and with the start of the Great Leap Forward in China in 1958. As we will see, the work of the Chinese and Japanese journalists was closely tied to these ups and downs in Sino-Japanese trade.

The Chinese saw the trade and other negotiations, such as those on the repatriation of Japanese who had remained in China after I945, as an opportunity to create a transnational network involving actors from both sides, aimed at the improvement of ties and establishment of official relations in the long term. This was encouraged and managed in detail by Liao Chengzhi. ${ }^{18}$ From the start, the work of those Chinese journalists reporting on Japan was integrated with these efforts. In addition to the long-term goal of cultivating connections with Japanese journalists, their task in the first half of the I950s was mainly to influence coverage on China in the Japanese media through direct propaganda. Furthermore, they facilitated reporting on Japan in the Chinese media in a way that supported Beijing's overall Japan policy, especially by emphasizing how numerous Japanese were supportive of the new government in Beijing. The Chinese journalists involved usually had long-standing ties to Japan and were often overseas Chinese originally from Japan or Chinese from the northeast of the country who had grown up under Japanese rule. Many of them had attended Japanese universities before i945. A first effort at promoting China in Japan was the founding of the Japanese-language propaganda magazine Jinmin Chügoku (People's China) in 1953 by Liao Chengzhi. Liao involved two young journalists who were fluent in Japanese in running the magazine: Liu Deyou, who was from the northeastern city of Dalian and would soon become a prominent Japanese interpreter for the Chinese leadership, and Kang Dachuan, who was originally from Taiwan, had been educated in Japan, and had moved to mainland China in $193^{8}$ to take part in the anti-Japanese struggle.

At the Xinhua News Agency, the most prominent Japan specialists were Wu Xuewen, also from Dalian, and Ding Tuo, an overseas Chinese originally from Southeast Asia. They had both studied in Japan and had been involved with Xinhua since the Sino-Japanese war. The Chinese journalists at Xinhua and Chinese newspapers who were assigned to write about Japan first had to understand Beijing's Japan policy and therefore the aims of the Chinese had to be clearly

${ }^{18}$ Casper Wits, 'The Japan Group: Managing China's people's diplomacy toward Japan in the I950s'. East Asia 33.2 (2016), pp. Io6, I07. 
articulated, to the journalists and then, through their reporting, to a domestic audience. According to $\mathrm{Wu}$ Xuewen, Xinhua's principles regarding reporting on Japan were to:

I. Emphasize the Sino-Japanese nongovernmental exchange and Sino-Japanese friendship activities

2. Support the Japanese people's struggle for peace, democracy, and sovereignty

3. Expose the Japanese government's hostility to China and pursuit of any Two China scheme

4. Have an appropriate amount of reporting on Japan's politics, economics, society, and international relations. ${ }^{19}$

These guidelines served to promote the idea of Sino-Japanese trade and people's diplomacy among a Chinese population for whom the memory of Japanese aggression was still raw. One of the journalists' first tasks was to get a grasp of who was who in Japan and what their opinion of China was. $\mathrm{Wu}$ Xuewen recalls that Liao Chengzhi gave the Xinhua journalists detailed instructions on who they should focus on and urged them to compile lists of important Japanese:

Liao's order was to report widely on influential Japanese people from various fields, and he went so far as to rearrange the names or add new ones. From this moment onwards, the names appearing in Xinhua's reports on Japan were often the same ones, and this was in close alignment with the policy of 'People-to-People Diplomacy'. ${ }^{20}$

By drawing attention to 'Japanese friends' who were sympathetic to the PRC, they sought to draw a clear distinction between Japan's leaders and its people. This in turn served to aid the effort to 'build a base of support within China and Japan for undermining American imperialism in Asia'. ${ }^{21}$

In the I950s, the nominally nongovernmental negotiations were the only times at which Chinese journalists could interact with Japanese and engage in first-hand reporting from Japan. Priority was given to deepening their connections inside the country generally and with Japanese journalists specifically. For example, during the 1953 visit led

${ }^{19} \mathrm{Wu}$ Xuewen and Wang Junyan, Liao Chengzhi yu Riben (Liao Chengzhi and Japan) (Beijing: Zhonggongdangshi chubanshe, 2007), p. 332.

${ }^{20}$ Ibid., p. 333 .

${ }^{21}$ Amy King, 'Reconstructing China: Japanese technicians and industrialization in the early years of the People's Republic of China'. Modern Asian Studies 50.I (2016), p. I67. 
by the Japanese Red Cross to China to discuss the repatriation issue, $\mathrm{Wu}$ Xuewen was instructed by Liao to interact especially with Japanese journalists in the delegation. ${ }^{22}$ When the reciprocal Chinese Red Cross delegation visited Japan in 1954, Wu Xuewen joined it and made the first-ever dispatch from Japan on behalf of Xinhua. ${ }^{23}$ With a network in Japan that was still very limited, Wu relied on overseas Chinese journalists sympathetic to Beijing to obtain a press card, necessary for sending dispatches, since Xinhua had no official relations with its Japanese counterpart, Kyōdō. ${ }^{24}$

In order to deepen their ties to Japanese journalists it was decided to seek out the most obvious channel for interaction: the Japan Newspaper Publishers and Editors Association (Nihon Shimbun Kyōkai, NSK). For this reason Kang Dachuan and Wang Xi of the People's Daily were included in a Chinese trade delegation that visited Japan in the spring of 1955. A meeting was held with NSK representatives in their hotel in Tokyo, where they indicated that many Japanese journalists were interested in visiting China. After consulting with Liao Chengzhi, an NSK delegation was invited to China in August $1955 .{ }^{25}$ The delegation was headed by Yokota Minoru, the deputy president of Sankei Shimbun, who had previously been foreign correspondent in Beijing for the Dōmei News Agency before $1945 .{ }^{26}$ The highlight of their visit was a lengthy meeting with Zhou Enlai on i7 August, at which many Chinese journalists were also present, including Wu Lengxi, the head of Xinhua, and Liu Deyou, who served as an interpreter, together with another of Liao's senior Japan hands, Zhao Anbo. ${ }^{27}$ The growing trust between the two sides eventually led the Chinese Journalists' Association (Zhongguo xinwen gongzuozhe xiehui) - the NSK's Chinese counterpart - to formally request permission from the Japanese Ministry of Foreign Affairs (MOFA) in September ${ }_{195} 6$ to send two correspondents, namely $\mathrm{Wu}$ Xuewen and Ding Tuo, to be stationed in

\footnotetext{
${ }^{22} \mathrm{Wu}$ and Wang, Liao Chengzhi yu Riben, p. I5o.

${ }^{23}$ Wu Xuewen, 'Dongjing diyi bao' (The first cable from Tokyo), in Huimou Dongjing (Looking Back at Tokyo) (Beijing: Zhongguo qingnian chubanshe, 1998), pp. I5-19.

${ }^{24}$ Ibid., pp. I8, I9.

${ }^{25}$ Nihon Shimbun Kyōkai jūnen shi (A Ten Year History of the NSK) (Tokyo: Nihon Shimbun Kyōkai, I956), pp. 436, 437 .

${ }^{26}$ Ibid., p. 437.

${ }^{27} \mathrm{Wu}$ Xuewen, Fengyu yinqing: Wo suo jinglide Zhongri guanxi zuozhe (Good Times, Bad Times: My Experience of Sino-Japanese Relations) (Beijing: Shijie zhishi chubanshe, 2002), pp. I64, I65.
} 
Japan. This was done with the endorsement of the NSK, who would then be able to send two Japanese correspondents to China in return. ${ }^{28}$ However, as was often the case with Sino-Japanese interactions in this era, the growing willingness of Japanese nongovernmental actors to engage with their Chinese counterparts was not matched with similar enthusiasm inside the Japanese bureaucracy. No response came from MOFA, and when Kishi Nobusuke became Japanese prime minister in February 1957, an exchange of correspondents became increasingly unlikely. This was despite the further efforts of $\mathrm{Wu}$ Xuewen and Ding Tuo on two visits to Japan in August and December 1957. Together with Yokota Minoru, they tried to use continuing momentum among Japanese news organizations, most of which were still keen to send correspondents, to achieve the exchange. ${ }^{29}$ From early $195^{8}$ the relationship between Japan and China deteriorated rapidly, due to both Kishi's pro-Taiwan stance and a radicalization in foreign policy following the start of the Great Leap Forward in China. The Chinese completely suspended trade with Japan after the Nagasaki Flag Incident on 2 May, when Japanese pulled down a PRC flag at a Chinese stamp exhibition in a Nagasaki department store. In fact, the Chinese had already broken off contact with Japanese journalists in the NSK in February, after it had sent a delegation to Taiwan. ${ }^{30}$ During the remainder of Kishi's tenure as prime minister until July ig6o, efforts were made to restore trade ties through channels established in the context of the previous decade's people's diplomacy. While some high-profile visits from Japan Socialist Party (JSP) leaders were made in this period, it was two visits in 1959 by Liberal Democratic Party (LDP) politicians - ex-prime minister Ishibashi Tanzan in September and ex-government minister Matsumura Kenzō in October - that arguably did most to restore high-level communications. ${ }^{31}$ For example, Matsumura returned to Japan with an invitation for Takasaki

${ }^{28}$ Nihon Shimbun Kyōkai nijūnen shi (A Twenty Year History of the NSK) (Tokyo: Nihon Shimbun Kyōkai, I966), pp. 484, 485.

${ }^{29}$ Ibid.

${ }^{30}$ The NSK insisted on having relations with both Chinas, a policy that actually predated the Kishi government. The official NSK history states that the breakdown in trust in February $195^{8}$ was in response to its insistence on 'the principle that the mutual exchange of journalists should be separated from politics'. Nihon Shimbun Kyōkai nijūnen shi, p. 482 .

${ }^{31}$ For a detailed overview of the efforts to restore Sino-Japanese trade and cultural relations in the 1958-1959 period, see: Caroline Rose, 'Breaking the Deadlock: Japan's informal diplomacy with the People's Republic of China, 1958-9', in Iokibe Makoto, 
Tatsunosuke to visit China in the following year. Takasaki was the former minister of trade and industry in the Kishi cabinet and would go on to play a central role in re-establishing Sino-Japanese trade links over the next few years. Although he was at first viewed with suspicion due to his perceived closeness to Kishi, Matsumura convinced the Chinese that Takasaki was the person best placed to aid them in improving trade relations with Japan. ${ }^{32}$

\section{The role of Matsumura Kenzō and Tagawa Seiichi}

Chairman Mao Zedong, as architect of the Great Leap Forward mass collectivization campaign which led to the disastrous famine from 1959 to I96I, was left marginalized during the first half of the ig6os, with economic policy now in the hands of other leaders. In addition to the economic devastation of the Great Leap Forward, the loss of economic support from the Soviet Union exacerbated the urgent need for foreign trade. In the following years China would take significant steps to engage with the capitalist world, building on the nongovernmental exchanges that had begun in the 1950s. In 1964, diplomatic normalization was achieved between the PRC and France, a trade agreement was reached with Italy, ${ }^{33}$ and (ultimately unsuccessful) trade talks were held with West Germany. ${ }^{34}$ However, it was access to Japanese markets and technology in particular that was now more important than ever, ${ }^{35}$ and by 1965 Japan would become China's most important trade partner. This was in no small part thanks to Japanese Prime Minister Ikeda Hayato, who was in office from July ig6o until November ig64. Though constrained by Japan's alliance with the United States in terms of seeking diplomatic normalization with the PRC, Ikeda was keen to strengthen Sino-Japanese trade relations. Realizing he could not openly take the lead in these efforts without

Caroline Rose, Tomaru Junko and John Weste (eds), Japanese Diplomacy in the I950s: From Isolation to Integration (Oxford/New York: Routledge, 2008), pp. I8I-I99.

${ }^{32}$ For the significance of Takasaki's i96o visit for Sino-Japanese economic relations, see:

King, China-fapan Relations after World War Two, pp. I88-I92; Itoh, Pioneers of Sino-Fapanese Relations, pp. III-II5.

${ }^{33}$ Carla Meneguzzi Rostagni, 'The China Question in Italian Foreign Policy'. Modern Asian Studies 5.I. (2017), pp. I22-124.

${ }^{34}$ Albers, Britain, France, West Germany and the People's Republic of China, pp. 3I, 32.

${ }^{35}$ King, China-Japan Relations after World War Two, pp. 197, 198. 
angering the Taiwanese and the Americans, he requested LDP parliamentarian Matsumura Kenzō, who had already gained the trust of the Chinese leadership, to act as his unofficial 'face' towards China. ${ }^{36}$ While communicating to the Chinese that he would not be cowed by foreign pressure when it came to expanding Sino-Japanese trade, Ikeda also made sure any trade agreement with the PRC would not offer them any advantages not enjoyed other countries, most notably Taiwan. ${ }^{37}$

The Chinese made use of this momentum by actively seeking to expand trade with Japan, first formalizing previous trade patterns that focused on progressive pro-China firms in so-called 'Friendship Trade' in August I960. By ig62 Zhou Enlai was convinced of the need to expand further and start trading with Japan's major corporations. ${ }^{38}$ This necessitated an engagement with more mainstream sections of the Japanese political and economic establishment. The fact that the Chinese did not have an embassy or any other permanent presence in Japan meant that Beijing's contacts in the country had mostly been progressive sympathizers of the PRC, often linked to the JSP and Japan Communist Party (JCP). Even during the trade negotiations in the I950s the Chinese mostly came in contact with Japanese left-wing economic groups. Amy King has described how the Chinese leadership harboured certain mistaken ideas about Japanese economic development, especially concerning the central role played by the United States, due to its reliance on this particular leftist subsection of the Japanese population. ${ }^{39}$ There was some awareness of this in Beijing and already by the mid-i95os one of the concerns for Liao Chengzhi and the Chinese leadership was the cultivation of ties with non-traditional allies beyond the Japanese left. ${ }^{40}$ Although this was a slow process, by the early ig6os it had begun to bear fruit, slowly creating a more balanced picture of Japan for the Chinese government. ${ }^{41}$ The Chinese were especially interested in

\footnotetext{
${ }^{36}$ Sun Pinghua, Chügoku to Nihon no hashi wo kaketa otoko (The Man who Built a Bridge between China and Japan) (Tokyo: Nihon keizai shimbunsha, I998), p. I02; Itoh, Pioneers of Sino-fapanese Relations, p. I12.

${ }^{37}$ Sun, Chügoku to Nihon no hashi wo kaketa otoko, p. II4; Soeya, Japan's Economic Diplomacy with China, p. 86.

${ }^{38}$ King, China-Japan Relations after World War Two, p. I8o.

${ }^{39}$ Ibid., pp. I59, I6o.

${ }^{40} \mathrm{Wu}$ and Wang, Liao Chengzhi yu Riben, p. I20.

${ }^{41}$ King, China-Fapan Relations after World War Two, pp. I88-igo.
} 
establishing links with conservative politicians within the LDP, who would form a pro-China faction within the party. Matsumura Kenzō was the most important among them; after gaining the trust of the Chinese, he was central in linking many influential figures in Japan with the Chinese leadership. During Matsumura's I959 visit to China he had suggested to his hosts that he could form an alliance with Takasaki Tatsunosuke for the improvement of Sino-Japanese relations, with Matsumura taking care of political matters and Takasaki focusing on economic ties. ${ }^{42}$ Eventually this led to Liao Chengzhi and Takasaki Tatsunosuke signing the 'LT (Liao-Takasaki)' Trade Agreement on 9 November 1962, which formalized China's trading patterns with large Japanese corporations and would lead to a rapid increase in trade. ${ }^{43}$ Liu Deyou describes the historical moment:

The LT Trade Agreement was an important step forward into another era for Sino-Japanese relations; going from a purely people-to-people stage to a half-governmental, half-civilian stage ... It is my opinion that with the LT Trade Agreement, and within that framework the realization of the Journalist Exchange, the second stage of [postwar] Sino-Japanese relations started. This stage lasted from 1962 until the diplomatic normalization of $1972 .{ }^{44}$

The Chinese perception that relations had entered a 'half-governmental' stage is backed up by the fact that the Japanese government tacitly supported Matsumura's efforts, as did many factions of the LDP, including Ikeda's own, whose member Ogawa Heiji would accompany Matsumura to China in ${ }^{1962 .}{ }^{45}$ During this visit Matsumura stated that an improvement in Sino-Japanese relations should be based on Zhou's 'Three Political Principles' ${ }^{46}$ and the non-separation of politics and economics. For the Chinese this was a prerequisite for progress on issues regarding trade as well as the

${ }^{42}$ Sun, Chügoku to Nihon no hashi wo kaketa otoko, pp. I03, I04.

${ }^{43}$ For an overview of LT Trade, see: Soeya, Japan's Economic Diplomacy with China, pp. 79-105.

${ }^{44}$ Liu Deyou, interview by author, Beijing, 25 August 2014.

${ }^{45}$ According to Tagawa Seiichi, other factions that had expressed their support were those of Kōno Ichirō, Fuijiyama Aiichirō, and Miki Takeo. See: Tagawa Seiichi, Nitchū kōshō hiroku (Private Papers on Negotiations between Japan and China) (Tokyo: Mainichi Shimbunsha, I973), pp. 32, 33 .

${ }^{46}$ The 'Three Political Principles' for Sino-Japanese relations, first articulated by the Chinese in 1958, were for Japan not to: adopt any policy hostile to China; engage in any plot to create Two Chinas; obstruct the normalization of relations with China. 
journalist exchange. ${ }^{47}$ In private, Liao Chengzhi assured Matsumura that the establishment of diplomatic relations was not a prerequisite for moving forward on trade. ${ }^{48}$ While the 1962 visit was important because of the trade agreement and subsequent rapid increase in Sino-Japanese trade, Matsumura also stressed the importance of the journalist exchange to further mutual understanding. This was in response to complaints by Zhou Enlai regarding misunderstandings about China that had appeared in the Japanese media. ${ }^{49}$ By the time of the next visit to China of Matsumura and his associates in the spring of ig64, Takasaki Tatsunosuke had died and his role was taken over by Okazaki Kaheita. On i9 April 1964, Liao Chengzhi and Okazaki Kaheita signed another agreement on LT Trade, leading to the establishment of trade liaison offices in Beijing and Tokyo, in August I964 and January I965 respectively. On the same day Liao and Matsumura signed the Sino-Japanese Journalist Exchange Agreement, which would lead to the exchange of correspondents in September of that year.

Together with his associate Tagawa Seiichi, Matsumura had been the main channel for the achievement of a journalist exchange on terms acceptable to Beijing. The motivation for this was connected to the Chinese leadership's limited understanding of Japanese realities, described above. According to Tagawa, he and Matsumura also thought a central problem in dealing with China was that there the 'information about Japan is biased, and this is because the information entering China comes from the Japanese left'. ${ }^{50}$ To improve Sino-Japanese relations and aid the burgeoning trade ties, they thought it necessary to widen the Chinese perspective. An important tool for this was a permanent presence of journalists in each other's countries, who could serve as a source of information and thereby enhance mutual understanding.

Several people in the LDP's pro-China faction around Matsumuralike Takasaki Tatsunosuke, Okazaki Kaheita, Furui Yoshimi, and Tagawa Seiichi-were involved in his dealings with China. While Takasaki and Okazaki would become the central figures in improving

${ }^{47}$ Liu Deyou, 'Chūnichi kankei seijōka ni tōhonseisō' (Efforts for the normalization of Sino-Japanese relations), in Wasuregataki saigetsu: Kishatachi no mita Chünichi ryōkoku kankei (Unforgettable Times: The Sino-Japanese Relationship as Seen by Journalists) (Beijing: Wuzhou Chuanbo chubanshe/TBS kyōryoku, 2007), p. 35.

${ }^{48}$ King, China-Japan Relations after World War Two, p. I52.

${ }^{49}$ Tagawa, Nitchū kōshō hiroku, p. 40.

${ }^{50}$ Ibid., p. 4I. 
trade relations and Furui Yoshimi would become a key political ally for China in the party, it was Tagawa who was most influential in working for the establishment of the journalist exchange. Tagawa had been an Asahi Shimbun journalist before he was recruited by Matsumura to be his secretary and then he was elected to the Diet for the LDP in 1960. The growth in trade in the wake of the establishment of the LT Trade Agreement in 1962 increased the need for permanent representation in the form of trade liaison offices in each other's countries. Against the background of these developments, Tagawa worked to achieve an exchange of correspondents. According to Liu Deyou:

By ig64 the amount of annual trade involved in LT Trade had reached $\$$ Ioo million. When this happened permanent offices became a necessity, and within that discussion Tagawa had been actively arguing for some time that a Journalist Exchange was also necessary. Looking at it now an exchange of journalists seems like nothing but at the time it was a political problem. Would it be permitted or not? Would permanent offices be permitted or not? This was one landmark decision. When it was permitted it was an important event in the preparation for a new era. ${ }^{51}$

For the Chinese, the permanent presence in Japan of both trade envoys and journalists would be an important step towards establishing official relations. As we will see, this was a point that Liao Chengzhi repeatedly stressed to the journalists who were to take part in the exchange.

With a journalist exchange becoming increasingly likely during the Ikeda years, news organizations on both sides were keen to place correspondents in each other's countries. At first the Japanese still expected this to happen via the NSK, but due to it continuing relations with Taiwan, the Chinese could not accept this and further attempts from the NSK to facilitate the journalist exchange were ignored. ${ }^{52} \mathrm{Wu}$ Xuewen says that 'when [the Japanese] learned of our stance they agreed to achieve the mutual exchange of journalists via direct negotiations between Liao and Matsumura'. ${ }^{53}$ This was still a long process and negotiations had to take place in a largely informal capacity due to factors like Taiwanese opposition and the pro-Taiwan faction in the LDP. With the increase in cultural exchanges between China and Japan under Ikeda, Liao Chengzhi began to make use of Chinese groups visiting Japan by attaching his associates to these

\footnotetext{
${ }^{51}$ Liu Deyou, interview by author, Beijing, 25 August 2014.

${ }^{52}$ Nihon Shimbun Kyōkai nijūnen shi, p. 486.

${ }^{53} \mathrm{Wu}$ and Wang, Liao Chengzhi yu Riben, p. 347.
} 
delegations. While in Japan they could meet freely with partners for the discussion about trade and the journalist exchange. Prominent Japan specialists Sun Pinghua and Wang Xiaoyun made several trips to Japan in this way in 1963 and 1964 , where they met Matsumura, Takasaki, and Furui to discuss both trade and the journalist exchange. Both sides were resolved to achieve a breakthrough on both these fronts as soon as possible. ${ }^{54}$ Tagawa Seiichi then visited China in February ig64 to discuss further the exchange - the Chinese people involved regarded his input at this moment as highly significant. ${ }^{55}$ The official reason for the visit was to have a meeting with the Chinese Red Cross about the right of Japanese to visit their relatives' graves in China, but this was a cover to discuss the journalist exchange as well as the establishment of the trade liaison offices. ${ }^{56}$ Tagawa stresses that while he undertook this trip in an informal and individual capacity and was not an official envoy, he felt that he had tacit yet strong support from both the Japanese government and many in the LDP. ${ }^{57}$ Liu Deyou recalls how it was also clear to the Chinese that Tagawa's efforts had the backing of a great many Japanese news organizations. ${ }^{58}$

On this visit to Beijing, Tagawa had meetings with Liao Chengzhi and several of his associates like Xiao Xiangqian, Ding Tuo, and $\mathrm{Wu}$ Xuewen. ${ }^{59}$ The importance of the exchange for the Chinese is shown by the fact that when Tagawa first suggested that one newspaper and one broadcaster from each country should both exchange one journalist, Liao unexpectedly suggested the exchange should involve journalists from more organizations. ${ }^{60}$ Tagawa also conveyed a message directly from Prime Minister Ikeda, who requested the Chinese to invite Matsumura to China once again. ${ }^{61}$ Upon returning to Japan, Tagawa had meetings with government officials and many news organizations,

\footnotetext{
${ }^{54} \mathrm{Wu}$ Xuewen, 'Chūnichi shimbun kōkan e no tōki michinori' (The long road towards the Sino-Japanese Journalist Exchange), in Shunka shüjitsu: nitchū kisha kōkan 4oshū nen no kaisō (Flowers in Spring, Fruits in Autumn: Memories of 4o Years of Japan-China Journalist Exchange) (Tokyo: Nihon Kyōhōsha, 2005), pp. 274, 275; Sun, Chügoku to Nihon no hashi wo kaketa otoko, p. II9.

${ }^{55}$ Liu, 'Chūnichi kisha kōkan no kiroku', pp. I72, I73.

${ }^{56}$ Sun, Chügoku to Nihon no hashi wo kaketa otoko, p. II9.

${ }^{57}$ Tagawa, Nitchū kōshō hiroku, p. 53.

${ }^{58}$ Liu, 'Chūnichi kisha kōkan no kiroku', p. I73.

${ }^{59}$ Tagawa, Nitchū kōshō hiroku, pp. 54-58.

${ }^{60}$ Liu, 'Chūnichi kisha kōkan no kiroku', p. I73.

${ }^{61} \mathrm{Wu}$, 'Chūnichi shimbun kōkan e no tōki michinori', p. 275.
} 
conveying the opinions of the Chinese. ${ }^{62}$ Matsumura and his associates were then invited to visit China in April to finalize the agreements on the trade liaison offices and the journalist exchange. In the same month, an important Chinese trade delegation, led by Nan Hanchen, was to visit Japan, a delegation that would include $\mathrm{Wu}$ Xuewen.

Unsurprisingly, relations between Taipei and Tokyo had been deteriorating for some time due to increased economic cooperation between Japan and the PRC. Taiwanese retaliation against Japanese companies trading with the PRC had little effect, and by I964 many Japanese companies had realized the lucrative potential of trade with mainland China, at the expense of Taiwan. ${ }^{63}$ With a breakthrough in Sino-Japanese relations seemingly close, the pro-Taiwan faction in the LDP, largely made up of allies of former Prime Minister Kishi, made a last-ditch attempt to derail the exchange of trade envoys and journalists. One of the Japanese cabinet members who was in this faction was the justice minister Kaya Okinori. He tried to block Wu Xuewen from entering Japan with the Nan Hanchen delegation, which had the desired effect of angering the Chinese. Beijing then put the entire delegation as well as Matsumura's invitation on hold. ${ }^{64}$ This became a major scandal and the 'Wu problem' featured prominently in the news in early April, signalling the rift between the pro-Taiwan faction, on the one hand, and Matsumura's pro-China faction and Prime Minister Ikeda, on the other. ${ }^{65}$ Under pressure, Kaya Okinori, together with the foreign minister Ōhira Masayoshi, stated that during an earlier visit $\mathrm{Wu}$ had criticized Japan and therefore would be banned from visiting this time, but that the rest of the trade delegation was welcome. ${ }^{66}$ After a meeting with Furui Yoshimi, Ikeda publicly stated that he wished Matsumura's visit to China go ahead. ${ }^{67}$ According to Wu Xuewen, Zhou Enlai realized that if the negotiations in April were cancelled it

\footnotetext{
${ }^{62}$ Liu, 'Chūnichi kisha kōkan no kiroku', p. I73.

${ }^{63}$ Soeya, Japan's Economic Diplomacy with China, pp. 96-98; King, China-Japan Relations after World War Two, p. I82.

${ }^{64} \mathrm{Wu}$, 'Chūnichi shimbun kōkan e no tōki michinori', p. 276.

65 “'Gō mondai” de sakusen kaeru Shatō' (Socialist Party changes strategy through 'Wu problem'), Yomiuri Shimbun, 3 April ig64.

66 “"Kojin dake no mondai” Go shi nyūkoku kyohi hōshō hōkoku' ("“Only a problem of the individual" announces Justice Minister regarding Wu's denial of entry'), Yomiuri Shimbun, 3 April I964 (evening edition).

67 'Matsumura hōchū yotei-dōri ni shushō, Furui-shi ni ikō hyōmei' (Prime Minister announces intention to Furui that Matsumura should visit China as planned), Yomiuri Shimbun, 3 April I964 (evening edition).
} 
would be a major triumph for anti-PRC forces in Japan. Zhou therefore decided that the Nan Hanchen delegation could go to Japan without Wu and that Matsumura and his associates could come to China for the visit that would lead to the breakthrough on the trade liaison issue as well as the journalist exchange. ${ }^{68}$

According to Liu Deyou, who was the interpreter at the meetings between Zhou and Matsumura in April I964, the Sino-Japanese Journalist Exchange Agreement largely reflected China's wishes, especially with regard to the guarantee of safety and assurances about the treatment of the Chinese journalists, similar to that enjoyed by other correspondents in Japan. ${ }^{69}$ Although initially the agreement had been to send eight journalists each, the Chinese wound up sending seven and the Japanese sent nine. The establishment of both the trade liaison officesthe 'Liao Chengzhi Liaison Office' in Tokyo (in August 1964) and the 'Takasaki Tatsunosuke Liaison Office' in Beijing (in January ig65) — was a landmark achievement. Liao Chengzhi impressed upon Sun Pinghua (as the most senior person stationed in Tokyo, he would be in charge of both the trade envoys and the journalists) that it was 'a little like an embassy. It will give you all plenty of opportunity to demonstrate your abilities. ${ }^{70}$ At last, both countries had permanent representation in the other country and, especially for China, this was further evidence that Sino-Japanese relations had reached a new stage. Liu Deyou says:

We could send personnel to live there, and this was major progress. To be able to get to know each other was very important. The Japanese wanted to know about China. And of course the Chinese also wanted to know about Japan ... There was no embassy, but those who worked [in Japan] played an important role. The understanding of the Chinese was that we were representing China. ${ }^{71}$

Liu Deyou and the others clearly saw this as a step towards establishing official relations, both with Japan and the capitalist world. Martin Albers has described how the expectation in Beijing was that many other countries would follow France's lead after its recognition of the PRG in January I964. ${ }^{72}$ This, however, did not come to pass, and from I965 the atmosphere in China would become increasingly xenophobic, culminating in another period of radicalization and international

${ }^{68} \mathrm{Wu}$, 'Chūnichi shimbun kōkan e no tōki michinori', p. 276.

${ }^{69}$ Liu, 'Chūnichi kisha kōkan no kiroku', p. I74.

${ }^{70}$ Sun, Chügoku to Nihon no hashi wo kaketa otoko, p. I24.

${ }^{71}$ Liu Deyou, interview by author, Beijing, 25 August 2014.

${ }^{72}$ Albers, Britain, France, West Germany and the People's Republic of China, p. 28. 
isolation when Mao Zedong unleashed the Cultural Revolution's radical phase (I966-I969). Despite these later setbacks, in I964 significant steps were taken in China's gradual opening to the non-communist world. In the next section we will see how the Chinese journalists in Japan were urged to use this opportunity to solidify their position and establish a 'foothold' in the country.

\section{The Ghinese correspondents in Japan}

A clear sign of the importance placed on the journalist exchange by Beijing is the fact that usually only one or two, and in exceptional cases three, Chinese correspondents would be placed in a foreign country. The decision to send eight (later reduced to seven) to Japan surprised even the Chinese journalists themselves, and some expressed doubt that journalists with sufficient knowledge of Japan could be found at such short notice. ${ }^{73}$ According to $\mathrm{Wu}$ Xuewen, a list was quickly drawn up by Xinhua and the Foreign Affairs Office of the State Council, ${ }^{74}$ under which Liao Chengzhi and his Japan hands operated. Not all those selected had experience as newspaper journalists; for example, Liu Deyou recalls that 'at the time I was very active as an interpreter. I had also done reporting for the magazine [finmin Chügoku] so they must have thought I was suitable. I was summoned suddenly. ${ }^{, 75}$ All but one of the Chinese correspondents were fluent in Japanese, with transnational links to Japan that could be traced back to the pre-I945 era which made them especially suited for their pioneering task. Three of them had spent significant time there as students and two came from the northeast, where they had been exposed to the Japanese occupation from a young age. ${ }^{76}$ Two journalists - Liu Deyou and Liu Yazhoufrom this first generation of Chinese correspondents in Japan are still alive, and the former was interviewed for this article.

${ }^{73} \mathrm{Wu}$ and Wang, Liao Chengzhi yu Riben, p. 348.

${ }^{74}$ Ibid.

${ }^{75}$ Liu Deyou, interview by author, Beijing, 25 August 2014.

76 The correspondents were: Ding Tuo for the Xinhua News Agency, who was the most senior of the correspondents; Tian Jianong for the Beijing Daily; Li Guoren for the China News Service (Zhongguo xinwenshe), who was from Taiwan; Liu Zongmeng for the Dagong Daily; Liu Deyou for the Guangming Daily; Liu Yanzhou for the Wenhui Daily, who was the youngest of the group; and Li Hong for the People's Daily, who was the only member who did not speak Japanese. See: Wu and Wang, Liao Chengzhi yu Riben, p. $34^{8}$. 
The five Chinese trade representatives, headed by Sun Pinghua, sent to Tokyo to set up the Liao office arrived there in August ig64. The journalists would follow in late September of that year and received several weeks of rigorous training at the Xinhua offices. Starting in early July, Wu Xuewen compared the training to that undertaken before a war. The curriculum involved studying 'the Central Committee's principles behind the establishment of the Liao Office in Tokyo, and behind the sending of correspondents to Japan, as well as the general situation in Japan, Sino-Japanese relations, and the country's Japan policy'. ${ }^{77}$ At the end of their training period they received detailed instructions from Liao Chengzhi, who emphasized their role as pioneers and described the challenges involved in being the first generation of PRC journalists in Japan:

You will be beset by reactionaries wherever you go. They will hinder, restrict, and keep watch over you. You must be sufficiently prepared for this in your thinking. You all come from different backgrounds and now you must unite, help each other, be disciplined, develop your work, and you must make efforts to establish a long-term foothold.

Establishing a foothold in Japan was their shared task and they would represent different news organizations in name only. Liu Deyou says:

It had been agreed with the Japanese in the 1964 agreement that one [news] organisation would send one person. So everyone was nominally from a different organisation ... So I had to belong to some organisation and I was placed with the Guangming Daily. But in reality I was transferred to Xinhua and would work for them .... For the outside world we were called the 'Chinese journalists group' but internally we were one unit; the Xinhua Tokyo office. ${ }^{79}$

Crucially, another essential group task, Liao emphasized, was for the journalists to mix with a wide variety of Japanese:

The work of journalists is the work of making friends widely. In principle, you can mix with and befriend people from the left, the centre, and the right ... There are those people who oppose us today who might change tomorrow and become relatively friendly. When making friends you must think ahead. If in your surroundings you only have leftist friends or those who speak well of us, and no rightists or those who speak ill of us, your grasp of the situation is not

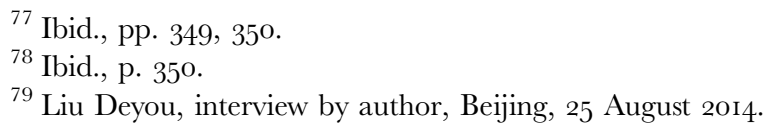


complete ... The more widely you have friends, the more useful it will be for you in establishing a long-term foothold. ${ }^{80}$

Not limiting themselves to mixing only with those Japanese already friendly to the PRC would not only enhance China's understanding of Japan, but would also contribute to their long-term presence in the country. Of course, this type of interaction was not without risks. On the eve of their departure, Liao Chengzhi invited Foreign Minister Chen Yi to address the journalists, who said: 'Japan is a capitalist country, you will live there long-term so you must make sure to "emerge from the mud unsoiled"."

The Liao office in Tokyo stayed in contact with Liao Chengzhi and the Foreign Affairs Office of the State Council; Sun Pinghua would keep Liao informed about the activities of the office as well as of the journalists. ${ }^{83}$ Both groups of journalists left at the same time, and on September 28 their paths crossed in Hong Kong, where they met for dinner. On the evening of the next day, both groups arrived at their destination. The Chinese were met at the airport by Sun Pinghua and by Japanese sympathizers. ${ }^{84}$ With their network in Japan still limited, in the beginning they relied largely on Japanese sympathizers for practical matters, as well as on overseas Chinese, thereby making use of their contacts from a previous era. ${ }^{85}$ At first the group stayed in the Diamond Hotel in Tokyo's Chiyoda ward, but after a few days they moved to the Grand Hotel in the same ward. Located conveniently close to the Diet building, they were able to use the hotel as an office. Ding Tuo, as

${ }^{80} \mathrm{Wu}$ and Wang, Liao Chengzhi yu Riben, p. $35^{\mathrm{o}}$.

${ }^{81}$ Ibid.

${ }^{82}$ Chen Yi's warning about the dangers of mixing with capitalists did not mean he was opposed to these types of exchanges. For example, he was very active in establishing nongovernmental trade channels with Western Europe in this period, especially with Italy. See: Meneguzzi Rostagni, 'The China Question in Italian Foreign Policy', p. I20. There is also little evidence of general opposition to the exchange among the Chinese leadership. Mao Zedong seems to have supported the engagement with the Japanese mainstream and centre-right. See, for example: Shiroyama Hidemi, "Moto gunjin hōchū-dan" to Mōtakutō gaikō no senryaku-sei: Chūgoku gaikō tōan kara miru gunkoku shugi no seisan' ("The veteran delegation's China visit" and Mao Zedong's foreign policy strategy'). Soshio Saiensu I9 (2013), pp. 76-92.

${ }^{83} \mathrm{Wu}$ and Wang, Liao Chengzhi yu Riben, p. 351.

${ }^{84}$ Liu, 'Chūnichi kisha kōkan no kiroku', p. I75.

${ }^{85}$ Liu Deyou, Gu Juanmin, Ma Qiaoqin and Liu Yanzhou, 'Wangbuliao tamen' (We cannot forget them), in Zhuri jizhe sishi nian (Forty Years of Journalists in Japan) (Beijing: Renmin Chubanshe, 2004), pp. Io-I6. 
leader of the group of journalists, visited many news organizations in his first days as well as nongovernmental groups sympathetic to China. ${ }^{86}$ At the end of 1964, Sun Pinghua had found an appropriate building in Bunkyo ward for the Chinese of the Liao office as well as for the journalists, who were able to establish their offices and their homes there. ${ }^{87}$

Liu Deyou describes how the journalists worked ferociously to keep up with all the news in Japan; they would usually begin their working day by reading newspapers and magazines for two hours, and then would try to watch as much TV as they could. When something important had happened, the reading could take up the whole morning. ${ }^{88}$ While at first they had to rely on ideological sympathizers, they soon made efforts to mix with many people, as they had been instructed to do:

As the first generation of journalists we could not just stay in our rooms but had to go out and get our hands on some first-hand materials. So not only in Tokyo but in all areas we would attend meetings and discussions, and would visit people from various backgrounds. ${ }^{89}$

Not limiting themselves to Japanese leftists, Liu Yanzhou nonetheless recalls how his first impressions of Japan were of the widespread enthusiasm for improved relations with China and diplomatic normalization among all kinds of Japanese. ${ }^{90}$ While the Chinese journalists were relatively free to mix with people, they would sometimes be openly shadowed by plainclothes police. They were told it was for their own safety, although Japanese friends told Liu Deyou that their real purpose was more likely to be to intimidate them. ${ }^{91}$ Tagawa Seiichi has described how, to his dismay, the Chinese journalists were subjected to discriminatory treatment not faced by correspondents from other countries nor by the Japanese correspondents in Beijing; for example, there were certain restrictions on travel outside Tokyo and their Japanese interviewees were often questioned by the police after being interviewed. ${ }^{92}$ Also, their access to official meetings for foreign

${ }^{86}$ Liu, 'Chūnichi kisha kōkan no kiroku', p. I75.

${ }^{87}$ Ibid., p. I77.

${ }^{88}$ Ibid., p. I78.

${ }^{89}$ Ibid., p. I79.

${ }^{90}$ Liu Yanzhou, 'Jiuwen Xinyi' (Old words, new translations), in Zhuri jizhe sishi nian, p. 75 .

${ }^{91}$ Liu, 'Chūnichi kisha kōkan no kiroku', p. I79.

${ }^{92}$ Tagawa Seiichi, Nitchū kōryū to jimintō ryōshütachi (Japan-China Exchange and the LDP Leadership) (Tokyo: Yomiuri Shimbunsha, I983), p. Iog. 
correspondents, including press conferences, was limited because the Taiwanese Central News Agency (CNA) would be represented there. ${ }^{93}$ The working conditions for the Chinese correspondents would worsen significantly once Satō Eisaku became prime minister of Japan in November 1964, which shows both the limits of nongovernmental agreements and that they were not always supported unanimously within the Japanese establishment.

The journalist exchange came at a volatile moment in Sino-Japanese relations, due to Prime Minister Ikeda's worsening health and stepping down from office in November. This was preceded by a leadership contest within the LDP which the Chinese leadership followed closely. The Chinese correspondents threw themselves into covering the developing contest, which was a three-way election between Satō Eisaku, Kōno Ichirō, and Fujiyama Aiichirō. Liu Deyou describes his impression of the frenzied media coverage of the campaign, and his bemusement that, in reality, backroom deals brought Satō Eisaku to power, after Ikeda had endorsed him from his hospital bed. ${ }^{94}$ For months, the Chinese leadership had already been seeking to inform itself about possible successors to Ikeda and what each would mean for Beijing, because an anti-China politician in the mould of Kishi Nobusuke could potentially undo much of the recent progress. In April, Matsumura Kenzō had expressed to Zhou Enlai his preference for Fujiyama Aiichirō, explaining that an improvement in Sino-Japanese relations was most likely under his leadership. ${ }^{95}$ But in May, Satō Eisaku had also relayed a message to the Chinese via a member of his faction, assuring them that if he was to prevail in any future leadership contest he would strive to continue improving relations with the PRG. ${ }^{96}$ By the time Satō came to power, the Chinese, in fact, had a rather favourable opinion of him, despite him being Kishi's brother. ${ }^{97}$

However, relations would deteriorate very quickly after the establishment of the Satō government, which would prove to be much

${ }^{93}$ Liu Yanzhou, 'Zongfang Dongying' (Revisiting Japan), in Fengyu Dongïnglu (On the Hard Road to Tokyo) (Beijing: Renmin Ribao Chubanshe, 2016), p. 288.

${ }^{94}$ Liu Deyou, 'Ryūnen' saserareta jūgonen: tokuhain seikatsu no-to' (I5 years of yearly extensions: Notes from a correspondent's life), in Shunka shüjitsu, pp. 71, 72.

${ }^{95}$ Furukawa Mantarō, Nitchū sengo kankei shi (History of Postwar Japan-China Relations) (Tokyo: Hara Shōbō, I98i), pp. 228, 229.

${ }^{96}$ Ibid., p. 234.

${ }^{97}$ Soeya, Japan's Economic Diplomacy with China, 1945-1978, pp. 48, 49. 
more susceptible to pressure from Taiwan and the United States. ${ }^{98}$ One of Satō's first actions was to block a visit to Japan by Beijing mayor Peng Zhen. He also expressed gratitude to Chiang Kai-shek for the Treaty of Taipei of 1952, which had established peaceful relations between Tokyo and Taipei. ${ }^{99}$ While Satō did express a willingness to continue on the path taken by Ikeda regarding the promotion of Sino-Japanese trade, this meant an explicit separation of politics and economics that would not be welcomed by the Chinese. ${ }^{100}$ Looking at the Chinese reaction to Satō's rise, we get a sense of how Beijing intended to use the recently improved channels of communication. The Chinese correspondents in Tokyo were intensely focused on getting a grip on the ideas of the incoming prime minister, a particular challenge being the extreme vagueness of his statements, with Liu Deyou often finding himself unable to render them into intelligible Chinese. ${ }^{101}$ Back in Beijing, evaluating the incoming information about the new government was a priority for Liao Chengzhi and his associates, as it was for the remaining journalists. Wang Taiping, a Japan specialist in the Foreign Ministry who would be stationed as Beijing Daily correspondent in Tokyo from ig69 to i973, recalls:

In 1965 , at one of Liao Chengzhi's gatherings, all those active in Japanese affairs from different departments had come together to discuss the nature of the Satō Cabinet, which had been an order from Zhou Enlai. The meeting was held in the restaurant Hefeng in the Wangfujing area of Beijing and between twenty and thirty people attended. ${ }^{102}$

As the journalists and other Japan hands would come to realize, in many ways the Satō government would resemble Kishi's government as far as relations with China were concerned. This was reflected in the unfriendly treatment of the Chinese journalists in the Satō era. ${ }^{103}$ Still, throughout the Satō years (1964-1972), the Chinese in the Liao office and the correspondents who were based in Tokyo were able to remain and work there, although many were recalled during the Cultural Revolution. Eventually, using the Chinese journalists in Tokyo as a tool

\footnotetext{
${ }^{98}$ King, China-Japan Relations after World War Two, p. 203.

${ }^{99}$ Furukawa, Nitchū sengo kankei shi, pp. 232, 233.

${ }^{100}$ Ibid., p. 232.

${ }^{101}$ Liu, 'Ryūnen' saserareta jūgonen: tokuhain seikatsu no-to', p. 72.

${ }^{102}$ Wang Taiping, interview by author, Tokyo, I3 September 2013.

${ }^{103}$ Chen Bowei, 'Jiongran butongde liangci zhuri jingli' (Two entirely different experiences of living in Japan), in Fengyu Dongïnglu, p. I3.
} 
for gathering first-hand information on political developments would prove to be very important for Zhou Enlai in the heady days before Sino-Japanese rapprochement in 1972. Wang Taiping, in particular, known as the 'Foreign Ministry's correspondent' and who would go on to become Chinese consul general in several Japanese cities in the Ig9os and 200os, became a trusted source and go-between for Zhou and the Chinese leadership in this period. ${ }^{104}$

\section{The Japanese correspondents in China}

As described, in I964 China achieved several breakthroughs in its relations with capitalist countries, perhaps most notably the diplomatic normalization with France in January. However, Martin Albers has described how France was barely given any preferential treatment and French diplomats in Beijing were left largely in the dark with regard to developments in China. ${ }^{105}$ This must have been especially frustrating because the chance to be better informed had been a key motivation for the French in seeking official ties with Beijing. ${ }^{106}$ As for Western correspondents in China, as mentioned earlier, their presence was barely tolerated and they had very limited access to information. ${ }^{107}$ The contrast with the experience of the first generation of Japanese correspondents in China reveals just how unique their situation was and, by extension, how important relations with Japan were for China at this moment.

As we have seen, it was agreed that both countries would send eight correspondents - in the end, however, the Chinese sent seven and the Japanese sent nine. The Japanese requested this change because, although one television broadcaster was represented (namely, the national broadcaster NHK), commercial TV stations were excluded. Thanks to the mediation of Tagawa Seiichi, in July ig64 the Chinese agreed that the Japanese could send an extra correspondent, with a

${ }^{104}$ See: Wang Taiping, 'Nitchū kokkō kaifuku’ nikki: Gaikōbu no 'tokuhain' ga mita Nihon (Diary of Japan-China Diplomatic Normalization: Japan as Viewed by the Foreign Ministry's Correspondent) (Tokyo: Bensei Shuppan, 2012); Wang Taiping, 'Nanwang Zhou Zongli de jiejian' (A hard to forget meeting with Premier Zhou), in Fengyu Dongïnglu, pp. 22-29.

${ }_{105}$ Albers, Britain, France, West Germany and the People's Republic of China, pp. 27, 28.

${ }^{106}$ Romano, 'Waiting for de Gaulle: France's ten-year warm-up to recognizing the People's Republic of China', p. 64.

${ }^{107}$ Hooper, Foreigners under Mao, pp. I25-159. 
different commercial station dispatching a representative each year. ${ }^{108}$ In the first year the Tokyo Broadcasting System (TBS) sent Ōkoshi Yukio, one of the two surviving journalists from the first generation of Japanese correspondents in the PRC, both of whom were interviewed for this article. TBS already had a reputation for its China coverage; for example, it had conducted the first Japanese TV interview with Foreign Minister Chen Yi in June I964. ${ }^{109}$ The other Japanese journalist interviewed for this article is Suga Eiichi, of the Sankei Shimbun, stationed in Beijing from 1964 to 1968 . He was one of several of the first generation of Japanese correspondents who had lived in China in his youth before 1945 during the Japanese occupation. ${ }^{110}$

The nine journalists arrived in Beijing on 29 September ig64, having dined with their Chinese counterparts in Hong Kong the night before. It was $\mathrm{Wu}$ Xuewen, on the Chinese side, who was mainly responsible for the accommodation of the Japanese as well as arranging their travel from Hong Kong to Beijing. ${ }^{111}$ Ōkoshi Yukio describes how the general feeling among the Japanese correspondents was one of excitement about being part of the exchange and that all of them had generally favourable views of China. ${ }^{112}$ The journalists were housed in the Xinqiao Hotel in Beijing, where they also had office space. Within the Chinese Foreign Ministry the responsibility for foreign correspondents fell to the Press Bureau. Along with increasing interaction with Japanese came the need for more Japan specialists in the Foreign Ministry, and thus a lot of recent graduates in Japanese from Peking University and the Foreign Languages Institute had been recruited. A number of them were assigned to the Press Bureau to work with the unusually large number of Japanese journalists. For many, this was often the first step in a long career of working on and in Japan, and several went on to work at the Chinese embassy in Tokyo after

${ }^{108}$ Ōkoshi Yukio, 'Pekin tokuhain no hibi-shodai Pekin tokuhain no kaisō' (Days as Beijing correspondent-Memories of a first generation Beijing correspondent), in Wasuregataki saigetsu, p. 183 .

109 Ibid., p. I84.

${ }^{110}$ The correspondents were: Matsunō Tanio for the Asahi Shimbun; Nishimura Chūrō for the Yomiuri Shimbun; Arai Takeo for the Mainichi Shimbun; Samejima Keiji for the Nihon Keizai (Nikkei) Shimbun; Suga Eiichi for the Sankei Shimbun; Miyata Kōji for the Nishi Nihon Shimbun; Yamada Reizō for the Kyōdō News Agency; Kobayashi Kazuo for NHK; and Ōkoshi Yukio for TBS.

${ }^{111}$ Ōkoshi, 'Pekin tokuhain no hibi-shodai Pekin tokuhain no kaisō', p. I86.

112 Ibid., p. 182. 
1972. ${ }^{113}$ From the end of November, the Foreign Ministry assigned each of the Japanese correspondents a personal assistant. Although these were young Japan specialists, their role was somewhat similar to the 'minders' usually assigned to foreign residents in China. ${ }^{114}$ Ōkoshi was assigned recent Peking University graduate Li Hongmin. Sundays aside, Li would come to the Xinqiao Hotel every day from roam to 6pm, helping with translating whatever was needed, like the People's Daily editorial of the day, and accompanying Ōkoshi throughout the working day: 'when going out to gather material to report on, he would not only interpret but also help carrying the tape recorder and film materials; we would be always together'. ${ }^{115}$ Though he was constantly accompanied, Ōkoshi recalls that, contrary to his expectations, 'in my daily life in Beijing there were basically no restrictions in my freedom' and he was able to travel freely within the country. In fact, he spent more than 6o days outside of Beijing in his year in China; one particularly notable trip was when he and Li Hongmin travelled to Manchuria and encountered many Japanese who had remained there after I945. $^{116}$

Of the media from outside of the communist bloc, Reuters, Deutsche Presse-Agentur, Agence France-Presse as well as several Canadian correspondents were represented in China and all had to abide by the same rules for reporting. For specific investigative reporting, permission was required from the Foreign Ministry's Press Bureau and when they wanted to travel outside of Beijing, they needed permission for this from both the Press Bureau and the police, a process that could take one or two weeks. ${ }^{117}$ There were no press conferences in China at the time and generally news would be relayed by the Foreign Ministry via written announcements in Chinese, French, Russian, and English, for which the journalists would have to rush to the Ministry, often late at

${ }^{113}$ Two Japan hands given important roles in managing the journalists were Wang Zhenyu and Wang Yueqin. The former had graduated from Peking University in I964 and would later be press counsellor at the Tokyo embassy, while the latter had graduated from the same university the year before and in the I9gos would move to Tokyo as the wife of the Chinese diplomat and future ambassador to Japan, Xu Dunxin. See: Suga Eiichi, 'Mō Takutō shakaishugi-Chūgoku no fūkei' (Mao Zedong's socialist China's scenery), in Shunka shüjitsu, p. 54; and Ōkoshi, 'Pekin tokuhain no hibi-shodai Pekin tokuhain no kaisō', p. I86.

${ }^{114}$ Brady, Making the Foreign Serve China, p. I02.

${ }^{115}$ Ōkoshi, 'Pekin tokuhain no hibi-shodai Pekin tokuhain no kaisō', pp. I92, I93.

${ }^{116}$ Ibid., pp. I93-195.

${ }^{117}$ Suga, 'Mō Takutō shakaishugi-Chūgoku no fūkei', pp. 54, 55 . 
night. ${ }^{118}$ Naturally the journalists were keen to interview China's leaders, but this was not possible. When he requested this through the Press Bureau, Suga Eiichi was told that the leaders were too busy or that refusal was 'because the Chinese journalists in Tokyo are not able to meet with the leaders of the Japanese government'. ${ }^{119}$ The Chinese also seem to have distinguished between the Japanese media they considered friendly and those they believed to be relatively hostile, thereby following Zhou Enlai's first principle for interacting with foreign journalists: 'Do not reject those who come, but be discriminating in how you treat them. ${ }^{120}$ Ökoshi Yukio states:

On the road to Japan-China rapprochement, to put it negatively, [the Chinese] wanted to use the Japanese media to attract supporters. So they would make a sharp distinction [between friendly and hostile media]. For example, when announcing news and someone from Sankei was there, they would keep their distance. But with Kyōdo for example they had better relations. Wu Xuewen understood this situation very well. ${ }^{121}$

While the use of the correspondents from right-leaning media to spread pro-China news was limited, the Chinese did value these journalists as a source of information. This can be seen by the fact that all the Japanese journalists were granted a rare privilege - namely, the monthly 'breakfast meeting' with Liao Chengzhi-which gave them more personal interaction with Chinese officials than any of the other correspondents.

The Chinese were aware that the lack of direct communication with members of the government was a major handicap for foreign correspondents in China at the time. Wu Xuewen recalls that, with the large contingent of Japanese journalists due to join the ranks of foreign correspondents in September I964, it was Saionji Kinkazu who brought up this issue with Liao Chengzhi. ${ }^{122}$ Motivated by the desire to make the exchange a success and to get the most out of the presence of the

${ }^{118}$ Ōkoshi, 'Pekin tokuhain no hibi-shodai Pekin tokuhain no kaisō', p. I89.

${ }^{119}$ Suga, 'Mō Takutō shakaishugi-Chūgoku no fūkei', p. 6r.

${ }^{120}$ Brady, Making the Foreign Serve China, p. 98.

${ }^{121}$ Ōkoshi Yukio, interview by author, Tokyo, 27 October 20I4.

${ }^{122}$ Saionji Kinkazu was a central figure in Sino-Japanese relations at the time. He relocated to Beijing in $195^{8}$ and stayed there with his family until 1970 . Since he was a sympathizer of the Chinese government and also had connections in various important stratums of Japanese society due to his upper class background, he had been invited to Beijing to help manage and cultivate the many connections forged in the context of people's diplomacy. See: Wu, 'Chūnichi shimbun kōkan e no tōki michinori', p. 278; 
Japanese journalists (and undoubtedly also to positively influence coverage in the Japanese press), Liao decided to organize a monthly 'breakfast meeting' at Hefeng in the Wangfujing area of Beijing (at the time the only Japanese restaurant in the city). Liao would attend these meetings at which the Japanese journalists were able to freely ask questions, a unique opportunity denied to other foreign correspondents in Beijing, who viewed this treatment of their Japanese colleagues with envy. ${ }^{123}$

The existence of a Japanese restaurant in the heart of Beijing in the I96os was in itself a small achievement in Sino-Japanese cooperation and had been a project of Liao Chengzhi and Saionji Kinkazu. By I96I, the second year of the Ikeda government, friendly trade and other exchanges with Japan were increasing rapidly: at any one time around 20 Japanese from companies and business associations would be based for short periods in Beijing, all in the Xinqiao Hotel. In ig6r one of them was Minamimura Shirō: he had been stationed in China for six months, but in fact he was born in Dalian in 1928 and had lived in China until his early teens, and then on and off from the late I950s. In I96I he had befriended Saionji Kinkazu, who, Minamimura recalls, one day asked him to set up and manage a Japanese restaurant. ${ }^{124}$ Although there were no Japanese restaurants in Beijing at the time, there was a sizeable Japanese community in the northeast and Minamimura drew upon this expertise, for example, by recruiting cooks and acquiring tools like the usu bowl used for rice-pounding. Procuring fish was another difficulty, but it could be flown in from Dalian, Qingdao, or Ningbo: 'Since it was a project of Liao Chengzhi, anything was possible. ${ }^{125}$ Opened in the winter of $1962 / 1963$, the restaurant became a popular spot for the small Japanese community, including the correspondents after I964, with gatherings for festivals and rituals like the end-of-year mochitsuki rice-pounding. ${ }^{126}$ As noted earlier, the Chinese Japan specialists around Liao Chengzhi would also occasionally use the restaurant for their meetings. Although the restaurant was open to all, on ordinary days the customers were 'mostly [high-ranking] cadres ... most of the customers were of bureau chief

and Saionji Kinkazu, Kaikoroku 'Sugisarishi, Shōwa' (Memoirs of the Bygone Shōwa Era) (Tokyo: IPEC Press, I99i).

${ }^{123} \mathrm{Wu}$, 'Chūnichi shimbun kōkan e no tōki michinori', p. 279.

${ }^{124}$ Minamimura Shirō, interview by author, Yokohama, 30 January 2014.

125 Ibid.

${ }^{126}$ Ōkoshi, 'Pekin tokuhain no hibi-shodai Pekin tokuhain no kaisō', p. I94. 
level in some organisation'. ${ }^{127}$ The restaurant was created in anticipation of increasing interaction between the Chinese and Japanese from the early I96os onwards, signalling the optimism of the Ikeda era in Sino-Japanese relations. Liao Chengzhi had a vision for the restaurant as a meeting place for both sides and as 'a place of reception for those Japanese who would visit as part of the people-to-people exchanges'. ${ }^{128}$ Perhaps the clearest example of how Hefeng functioned as a place that facilitated Sino-Japanese interaction were the monthly breakfast meetings. Again, we can contrast this with the experience of the French, who opened a cultural centre in Beijing in I964 that would become a hub for interaction between foreigners, but that no Chinese were permitted to enter. ${ }^{129}$

The Hefeng meetings started soon after the Japanese journalists arrived in China, with the first meeting taking place on I2 October I964. ${ }^{130}$ Zhou Enlai had given his backing and Liao Chengzhi would often explicitly state that he was conveying Zhou's point of view. ${ }^{131}$ According to Ōkoshi Yukio:

Liao said: 'Let's speak informally and frankly, and without reservations on both sides.' This made for a very comfortable atmosphere from the start and it was as if we had been friends for years. The breakfast meetings were generally held in Japanese and organised by Liao Chengzhi and Saionji. The meetings were held for a year but stopped abruptly in the second year. ${ }^{132}$

Suga Eiichi recalls that 'we were told we could ask anything. Actually it was like a press conference. The one who led and spoke was Liao Chengzhi. ${ }^{133}$ As well as the Japanese correspondents and Saionji Kinkazu, on the Chinese side Liao would often be accompanied by around six associates. Ōkoshi Yukio describes the scene:

In Hefeng, apart from the seating area with chairs, there were three Japanese style rooms. For the breakfast meeting, the rooms would be added together, opening a long narrow space. The Japanese and Chinese would sit on opposite sides of a long table, with the Chinese on the wall side with Liao Chengzhi in the

${ }^{127}$ Minamimura Shirō, interview by author, Yokohama, 30 January 2014.

128 Ibid.

${ }^{129}$ Albers, Britain, France, West Germany and the People's Republic of China, p. 27.

${ }^{130}$ Ōkoshi, 'Pekin tokuhain no hibi-shodai Pekin tokuhain no kaisō', p. I9I.

${ }^{131}$ Iwaki Hiroyuki, 'Chūgoku no mado' (A window on China), in Wasuregataki saigetsu, p. 20I.

${ }_{132}$ Ōkoshi, 'Pekin tokuhain no hibi-shodai Pekin tokuhain no kaisō', p. I9ı.

${ }^{133}$ Suga Eiichi, interview by author, Tokyo, 20 June 2014. 
middle. Next to him would be Zhao Anbo and one or two people from the Foreign Ministry's Press Bureau. They would sit in order like they would in the office. Wang Zhenyu and Tang Jiaxuan were there sometimes. From the Liao Office Wang Xiaoyun and Xiao Xiangqian would be there. Saionji would be sitting in the corner on the Chinese side, observing carefully. Sometimes he would tell us afterwards 'don't ask such and such a question.' Wu Xuewen and others attended as well. ${ }^{134}$

As a unique space for interaction, the Hefeng meetings are an example of the openness of the early to mid-Ig6os. While this moment would not last, for young participants like the future Chinese foreign minister Tang Jiaxuan (1998-2003), these interactions were the first step in a long career in Chinese foreign affairs and Sino-Japanese relations in the decades to come.

Important news would be conveyed regularly at the meetings, which would last for about two hours, after which the journalists would rush back to the office. ${ }^{135}$ Suga Eiichi recalls that Liao had said to them they would be the first to hear certain news. This made the Japanese even better informed than diplomats from nations that had official relations with Beijing:

Liao had said: 'When there is important news, you Japanese correspondents will know even before [USSR news agency] TASS.' [Therefore] people from the French and Eastern European embassies, as well as the TASS and Pravda correspondents, would seek out the Japanese correspondents about the breakfast meeting. ${ }^{136}$

The Japanese were well aware of their privileged position and that this opportunity greatly surpassed a press conference in terms of the amount of interaction they had with government officials. ${ }^{137}$ This stood in stark contrast to the circumstances of the Chinese correspondents in Japan, who tended to come to the meetings when they were back for brief visits to Beijing. As Liu Deyou recalls:

During a holiday I attended once. Liao Chengzhi was a great speaker, very articulate. This was because he was so knowledgeable about Japan. The Japanese journalists also received information. I was in Japan so I felt very envious. At the Japanese Foreign Ministry press conferences the [Taiwanese] CNA was represented. ${ }^{138}$

\footnotetext{
${ }^{134}$ Ōkoshi Yukio, interview by author, Tokyo, 27 October 20I4.

${ }^{135}$ Suga Eiichi, interview by author, Tokyo, 20 June 2014.

${ }^{136}$ Suga, 'Mō Takutō shakaishugi-Chūgoku no fūkei', pp. 57, 58.

${ }^{137}$ Ōkoshi, 'Pekin tokuhain no hibi-shodai Pekin tokuhain no kaisō', p. I9o.

${ }^{138}$ Liu Deyou, interview by author, Beijing, 25 August 2014.
} 
As Liu notes, there was plenty of opportunity for the Japanese to receive information. Additionally they could also bring up topics they were interested in. This would often concern current affairs, such as the non-participation of China in the Tokyo Olympics and the Asia-Pacific Broadcasting Union, ${ }^{139}$ thereby clarifying the Chinese government's stance. $^{140}$ Suga Eiichi also describes how they would discuss Sino-Japanese and Sino-Soviet relations, the situation in Vietnam, and so on, thereby getting 'a good grasp of China's position and thinking, and it was a great resource for gaining an understanding of the situation'.

Much more than a mere question-and-answer session between the journalists and Liao, the latter used the breakfast meetings to keep a finger on the pulse of what was going on in Japan. According to Ōkoshi Yukio, the Japanese were well aware of this and that the Chinese, by 'using this route, hoped to obtain information that the Chinese Foreign Ministry did not have yet'. ${ }^{142}$ At the meetings, Liao wanted to discuss articles he had read in the Japanese press and would impress the Japanese by how informed he was about Japanese society. Ōkoshi recalls that

Liao Chengzhi would start by wishing everyone a good morning, and tell us to make ourselves comfortable. He spoke frankly. In my memory, he would often read [the Japanese magazines] Bungei shunjū, Sekai, and Chīō kōron and would ask: 'Who has written this?' and 'Did everyone read that?' His intention was to clarify the real meaning behind the article in question. ${ }^{143}$

Apart from such general discussions, Liao used the journalists to get a grip on recent political developments. As noted before, the Chinese were deeply concerned about the succession struggle in the last days of the Ikeda government in October and November I964, as Ikeda was dying from cancer. In fact, Liao had already expressed concern about the next government as early as the I962 talks with Matsumura Kenzō. ${ }^{144}$ Liao used the first few breakfast meetings to listen to the views of the

139 The Asia-Pacific Broadcasting Union (ABU) was founded in 1964 and exists to this day. As a result of the participation of the Taiwanese media, China refused to join the organization.

140 Ōkoshi Yukio, interview by author, Tokyo, 27 October 2014.

${ }^{141}$ Suga, 'Mō Takutō shakaishugi-Chūgoku no fūkei', p. 57 .

142 Ōkoshi Yukio, interview by author, Tokyo, 27 October 2014.

143 Ibid.

${ }^{144}$ Tagawa, Nitchū kōshō hiroku, p. $3^{6 .}$ 
journalists about the unfolding situation. From his persistence we can see how much interest the Chinese had in the unfolding leadership contest. According to Ōkoshi:

At the first breakfast meeting, Liao Chengzhi asked: 'Is Ikeda really that ill?' and 'If Ikeda retires who will be next?' as well as 'Will it be Fujiyama? Will it be Kōno? Will it be Satō?' and 'What does everyone think?' I remember this very clearly. And not only at the breakfast meetings; when we met him at parties and so on, he would go on and on about it. ${ }^{145}$

After the new Sato government was established, a lot of the discussions at the breakfast meetings focused on Sino-Japanese relations, what with changes in the Japanese political scene and the Japanese government's gradual move to the right. Ōkoshi says:

The Chinese were most interested in the political situation and trends in Japanese politics. On the Chinese side the goal of the 'Zhou-Liao line' was to realise diplomatic normalisation between Japan and China soon. Small steps forward had been made by the efforts of Matsumura and the establishment of the Ikeda government, but the establishment of the Sato government was a great setback. The Chinese wanted to know where this would lead. ${ }^{146}$

The founding of the Satō government set in motion another period of slow deterioration in Sino-Japanese relations. Eventually this led to the cancellation of the breakfast meetings. Suga states:

Liao Chengzhi would attack Satō vigorously ... In the end, the meetings were held twelve times until November 1965. [Of the journalists] only Samejima and I attended all twelve meetings. Its ending had a lot to do with the founding of the Satō government. Nothing [bad] would be said about Prime Minister Ikeda but Satō was much criticised.

While the Sato government's policies definitely contributed to the end of the era of relatively thriving Sino-Japanese relations, this also coincided with a period of rising xenophobia in China against foreigners in general. In 1964 and 1965 , increasing restrictions were placed on the activities of and interaction with foreigners, as a prelude to the radicalization of the Cultural Revolution which was to start in Ig66. $^{148}$

${ }^{145}$ Ōkoshi Yukio, interview by author, Tokyo, 27 October 20I4.

${ }^{146}$ Ibid.

${ }^{147}$ Suga Eiichi, interview by author, Tokyo, 20 June 2014.

${ }^{148}$ Brady, Making the Foreign Serve China, p. I30. 
The relative openness in China's outlook during the first half of the Ig6os made a high level of interaction possible for the Japanese correspondents when they first arrived in China. While this era was already coming to an end by the time the journalist exchange started, the ripples of goodwill would continue for a while and make the breakfast meetings possible. Despite this moment being short-lived, many of the participants would go on shaping Sino-Japanese relations in the decades after 1972, both as journalists and as diplomats. The exchanges were seen as positive and fruitful by both sides, and the breakfast meetings, with the unique level of access they provided to the Chinese leadership especially, are still viewed somewhat nostalgically by later generations of Japanese correspondents based in China. ${ }^{149}$ According to Minamimura Shirō, Hefeng was open from around ig62/ I963 to $1966 / 1967$, when the Cultural Revolution led to the restaurant to close its doors. ${ }^{150}$ The Cultural Revolution gradually resulted in all but the Asahi Shimbun correspondent being expelled from China, with a low point being the one-and-a-half year imprisonment of Nikkei Shimbun correspondent Samejima Keiji on charges of spying from June ig68. ${ }^{151}$ In the I970s, after diplomatic normalization, the relationship between Japan's newspapers and the Chinese government would enter a honeymoon period, however, with even right-leaning newspapers like Yomiuri Shimbun and Sankei Shimbun being swept up in a 'China boom' and producing gushing editorials about the virtues of China and its leadership. ${ }^{152}$

\section{Conclusion}

The Sino-Japanese journalist exchange was made possible by rapidly improving ties during a brief moment between ig6o and ig64 when the era of the relatively pro-China Ikeda Hayato government in Japan coincided with the Chinese government's efforts to engage with Japan and the capitalist world. Understanding the importance of this moment in Sino-Japanese relations brings into focus the history of the 1972

${ }^{149}$ Iwaki, 'Chūgoku no mado', pp. I98-207.

${ }^{150}$ Minamimura Shirō, interview by author, Yokohama, 30 January 2014.

${ }^{151}$ Samejima Keiji, Tsuisō (Recollections) (Tokyo: Nikkei Jigyō Shuppan Center, 2005), pp. $335^{-349}$.

${ }^{152}$ Jing Sun, 'China as Funhouse Mirror: Yomiuri Shimbun's China coverage during the Cultural Revolution'. Japanese Studies 28.2 (2008), pp. I79-196. 
diplomatic normalization and how its success was rooted in the efforts made in the previous decades.

Those involved in the exchange saw it as an important step in solidifying relations between China and Japan. Efforts by Japanese politicians like Matsumura Kenzō and Tagawa Seiichi laid the initial groundwork for achieving the exchange on the Japanese side. Likewise, the Chinese demonstrated the importance they placed on the exchange by the number of news correspondents they wanted to involve, as well as the high level of access the Japanese journalists were given. The Chinese leadership saw a permanent presence in each other's country, through both trade envoys and journalists, as an essential first foothold that would inevitably lead to diplomatic normalization, the achievement of which was seen as the potential start of a new era. This goal was largely shared by those politicians in Japan who had made the journalist exchange possible and also by many of the Japanese journalists. However, support for this was far from unanimous in the Japanese establishment. After the founding of the conservative Satō Eisaku government in November ig64, a lot of the goodwill evaporated, which was exacerbated by the anti-foreign sentiment that had already been growing in China before the start of the Cultural Revolution in May 1966.

For the Chinese, the importance of the journalist exchange lay, to a large extent, in using the correspondents involved as a source of information. Politicians in both countries felt that Beijing's lack of unbiased information about Japan, due to its reliance on leftist contacts, inhibited its understanding of Japanese society, hampered its ability to develop a sound Japan policy, and hindered the development of trade relations. The Chinese correspondents in Tokyo were urged to build a network that extended beyond China's natural sympathizers in Japan and, generally, to keep a finger on the pulse of Japanese society, thereby obtaining a more reliable stream of information. At the same time, the Japanese correspondents in Beijing were mined for information about political trends and specific politicians in Japan, again signalling the desire among the Chinese leadership for accurate information upon which they could base policy. In the autumn of 1964 we see an example of this in how Beijing used both groups of journalists to acquire information on the important actors in the transition from the Ikeda to the Satō government, in order to craft an informed Chinese response. As described, this fruitful exchange would soon be negatively affected by the deterioration of Sino-Japanese relations. 
In the I950s, the policies of conservative Japanese prime minister Kishi Nobusuke (I957-I960) and a general radicalization of Chinese politics led to a breakdown of trade relations in $195^{8}$, thereby showing the limits of nongovernmental agreements between Japan and China in that era. The significance of the breakthroughs achieved in the first half of the I96os can be seen in the fact that when relations again deteriorated after 1964, the trade liaison offices remained open and the journalist exchange continued. The achievements of ig64 were able to withstand the negative spiral of the following years, showing that relations had indeed entered a different stage. Further evidence of the importance of this moment is found in the fact that many of those directly participating in the exchange, as well as those who contributed to the exchange in a more indirect way, would continue to shape Sino-Japanese relations as journalists or diplomats in the diplomatic normalization process and beyond. 